\title{
An experimental study of combined operation of energy storage system and gas engine power plant in off-grid power system
}

\author{
Gleb Nesterenko ${ }^{1,2^{*}}$, Gleb Prankevich ${ }^{1}$, Aleksey Savitskiy ${ }^{1}$, Dmitriy Gladkov $^{2}$, Vyacheslav Zyryanov $^{2}$, Sergey Kuchak $^{2}$, and \\ Julia Mokrousova ${ }^{2}$ \\ ${ }^{1}$ Energy Storage Systems LLC, Novosibirsk, Russia \\ ${ }^{2}$ Novosibirsk State Technical University, Novosibirsk, Russia
}

\begin{abstract}
Test results of the main industrial prototype of energy storage system (ESS-10-1200-400) of nominal power $1200 \mathrm{kVA}$, energy capacity $400 \mathrm{kWh}$ and voltage $10 \mathrm{kV}$ based on lithium-ion batteries when operating in combination with gas engine generators (GEG) as a part of experimental power system with active abrupt variable load are given. Its structure, components and parameters, as well as the components and parameters of ESS are described. Tests have shown high operation capacity of the prototype tested, high efficiency of the implemented algorithms and confirmed the expediency of the use of ESS for smoothing power surges/sheddings in the GEG, thus preventing their emergency shutdown resulted from the power surge.
\end{abstract}

\section{Background}

At present the technologies of energy storage in Russia have reached the level of common practical application in the electrical power systems. Implementation of the energy storage systems (ESS) in the electric power systems of all types is one of the most important tendencies in the Russian power industry development. High-rate ESS allow solving a range of complex problems much more efficiently than traditional methods [1-5]. ESS is a multifunctional device capable of regulating active and reactive power, frequency, performing the functions of active filtering higher harmonics and compensation of three-phase voltage asymmetry.

Nowadays, the greatest technical and economic effect from the application of ESS can be obtained, first of all, at the objects of distributed generation, in Smart and Microgrids (including those operating on renewable energy), at off-grid power plants in oil and gas sector. The predominant part of the power generation at the mentioned above objects is generated mainly by diesel, gas turbine and gas engine units.

Gas engine generators (GEG), as well as diesel generator units (DGU), have high reliability in terms of structure, which makes it possible to work on inexpensive gaseous fuel (natural gas, propane, butane, associated petroleum gas, etc.), which, as a rule, is in abundance in places of oil and gas production.

At the same time the GEG, unlike the DGU, has a number of characteristic features [6]:

- in abrupt surges/sheddings of $10-20 \%$ of the rated power the GEG is shut down by technological protection system;
- surge/shedding rate should not exceed $1 \%$ per second of rated power of the GEG;

- during continuous operation, the load of the GEG must be at least $35-40 \%$ of the rated power.

The necessary consideration of these features in the process of GEG operation is especially important, because gas engine generators are widely used at off-grid power plants of oil and gas producing enterprises, the load of which has a pronounced abruptly variable stochastic character. This kind of the load, in addition to other negative effects, leads to increased wear of the equipment and, consequently, to increased costs for repair and maintenance of gas engine units.

This article describes the results of experimental tests and studies of energy storage system conducted by LLC "Energy Storage Systems", LLC "DC Systems" and NSTU on May 24, 2019 in Novosibirsk. The tests were carried out on the main industrial prototype ESS-101200-400 with nominal power of $1200 \mathrm{kVA}$, energy capacity of $400 \mathrm{kWh}$, nominal voltage of $10 \mathrm{kV}$ produced by LLC "Energy Storage Systems", designed to work as part of an off-grid power supply system based on GEG (Figure 1).

The aim of the tests is to verify that the main ESS prototype, the parameters of the system as a whole and each of its subsystems satisfy the requirements of the technical specification, to confirm the efficiency of ESS to ensure the smoothing mode of the load power surge/drop (limiting rate of increase/decrease of the power of the power consumed from the GEG). 


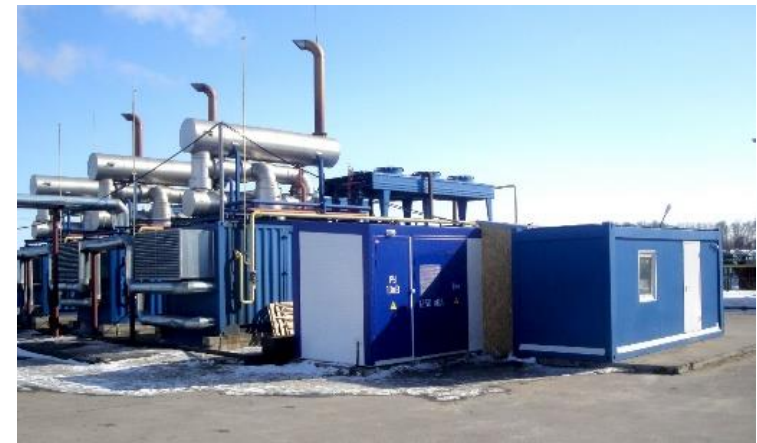

Fig. 1. Experimental power system for testing the combined work of ESS-10-1200-400 and GEG.

\section{Description of the experimental power system}

The circuit diagram of the experimental power system for testing ESS is shown in Figure 2. The experimental unit consists of two GEGs, power transformers, sectionalized active load, whose value is discretely changed by switching devices, energy storage system, control and recording equipment, control system.



Fig. 2. The principal scheme of the test experimental installation (ESS - energy storage system, Gen.1, Gen.2 - gas engine generators, T4.1, T4.2 - power transformers, R4.1-R4.6 - active load resistance, Q1, Q2, Q4. 1 - Q4.6 - circuit breakers, TV1 and TV2 - measuring voltage transformers, TA1.1 TA4.3 - measuring current transformers, HMI - humanmachine interface of a control subsystem, TA sum. - summing current transformer).

\section{Equipment components of the experimental power system}

Two gas engine generators GmbH MWM TCG 2020 V12K with generators AvK DIG $120 \mathrm{i} / 4$ working on natural gas are used in the experimental installation. Technical specifications of the GEG are given in Table 1 [7].

To simulate the active abruptly variable load, a load switching module was used, which allows to connect and disconnect the active load unit on a periodic predetermined base:

- 2 load blocks (modules) of IC-400-100, each of 100 $\mathrm{kW}$ active load;

- 2 loading blocks (LOAD BANKS), each of $400 \mathrm{~kW}$ active load (power of one of the blocks is artificially limited to $200 \mathrm{~kW}$ );

- 2 load blocks (electric heaters) KEV-60, each of $200 \mathrm{~kW}$ active load.

Table 1. Technical characteristics of gas engine generators for frequency of $50 \mathrm{~Hz}$.

\begin{tabular}{|c|c|}
\hline Electric power, $\mathrm{kW}$ & 1125 \\
\hline Thermal power, $\mathrm{kW}$ & 1253 \\
\hline Electrical efficiency, $\%$ & 40,9 \\
\hline Thermal efficiency, $\%$ & 45,6 \\
\hline Total efficiency, $\%$ & 86,5 \\
\hline $\begin{array}{c}\text { Overhaul when operating on } \\
\text { natural gas, through, } \mathrm{h}\end{array}$ & 64000 \\
\hline Speed of rotation, $\mathrm{min}^{-1}$ & 1500 \\
\hline Average piston speed, $\mathrm{m} / \mathrm{s}$. & 9,8 \\
\hline Dry unit weight, $\mathrm{kg}$ & 11700 \\
\hline
\end{tabular}

ESS-10-1200-400 was used as a test energy storage system. During testing, the ESS was used to provide a smoothing mode for the load power surges/sheddings in an experimental off-grid system. The connection between lithium-ion batteries and the power system was provided by a power transformer and a bidirectional transistor converter assembled in a classical three-phase bridge scheme.

The storage subsystem (SS) uses GBS-LFP100AH accumulators with the technical characteristics given in Table 2 [8]. The main SS element is the storage module MA6x200.600, which is a unit of six storage cells with a capacity of $200 \mathrm{Ah}$, serially connected, elements of the storage battery control system and a casing. Two modifications of the modules are used in ESS - positive and negative electrodes. Technical characteristics of the module are presented in Table 3 .

Table 2. Technical characteristics of the GBSLFP100AH.

\begin{tabular}{|c|c|}
\hline Capacity, $\mathrm{Ah}$ & 100 \\
\hline Material of positive electrode & lithium ferrum phosphate \\
\hline Nominal voltage, $\mathrm{V}$ & 3,2 \\
\hline Standard charge current, $\mathrm{C}_{\text {rate }}$ & 0,25 \\
\hline Standard discharge current, $\mathrm{C}_{\text {rate }}$ & 0,5 \\
\hline $\begin{array}{c}\text { Maximum continuous discharge } \\
\text { current, } \mathrm{C}_{\text {rate }}\end{array}$ & 3 \\
\hline Peak discharge current, $\mathrm{C}_{\text {rate }}$ & 10 \\
\hline Internal resistance, Ohm, $\max$ & 0,6 \\
\hline Self-discharge per month, $\%, \max$ & 1 \\
\hline
\end{tabular}


Table 2 extension. Technical characteristics of the GBSLFP100AH.

\begin{tabular}{|c|c|}
\hline $\begin{array}{c}\text { Number of charging cycles, once, } \\
\text { min }\end{array}$ & 2000 \\
\hline Weight, $\mathrm{kg}$ & 2,8 \\
\hline Overall dimensions, $\mathrm{LxWxAl}, \mathrm{mm}$ & $126 \times 65 \times 253$ \\
\hline Operating temperature, ${ }^{\circ} \mathrm{C}$ & $-20 \ldots+65$ \\
\hline
\end{tabular}

Note. The current value is indicated in $\mathrm{C}$-rate (relative units / hour), where $\mathrm{C}=100 \mathrm{Ah}$. For example, at $\mathrm{C}_{\text {rate }}=1$ current is $100 \mathrm{~A}$.

The modules are placed in six rows on racks. Each battery (of three) consists of two racks: in the first, besides 15 modules, there are switching power equipment and secondary circuits, and in the second there are 18 battery modules.

Table 3. Technical specifications of the MA6 6200.600 battery module.

\begin{tabular}{|c|c|}
\hline Battery type & GBS-LFP100AH \\
\hline Number of batteries & 12 \\
\hline Number of battery cells & 6 \\
\hline Nominal voltage, $\mathrm{V}$ & 19,2 \\
\hline
\end{tabular}

The electrical energy conversion subsystem is based on three three-phase power converters each of $400 \mathrm{kVA}$ and performs the following functions:

- transformation of three-phase voltage of alternating current of industrial frequency into voltage of direct current and charging of SS batteries;

- maintenance of SS accumulators in a mode providing their operability and the maximum resource;

- conversion of DC voltage into AC voltage of industrial frequency and power output to the load or to the grid.

In the converter control system the elements of the theory of instantaneous power and the block of phase locked loop $[9,10]$ are used.

\section{Test program}

GEG have serious limitations in terms of the allowable dynamic of load changes, making their application in power systems with abruptly variable load more difficult. Therefore, the main attention during the tests was paid to checking the efficiency and debugging of the ESS control algorithms to decrease the rate of the rate of power change of the GEG at abrupt load surges. The analysis of transient processes is of special interest, because the main specific features of changes in the operating parameters of off-grid power systems with GEG at oil and gas production enterprises are abrupt and deep sheddings and surges of frequency and voltage, accompanied by increased fuel and motor resource consumption, and at surges (more than $10-20 \%$ of the load capacity) - GEG shutdown by technological protection system.
Two algorithms were tested as possible ESS control algorithms for combined application with GEG in offgrid systems.

The first algorithm is designed for limiting the rate of change in generator power at abrupt changes of load (further - "dP/dt compensation mode "). When dumping or shedding the load ESS provides a smooth change in the generated power, significantly reducing the drops and outs of voltage, frequency, as well as excluding the possibility of shutdown of the GEG by the technological protection system.

The second algorithm is intended for limiting the maximum and minimum power generated by the GEG ("power limitation mode"). At peaks of consumption ESS outputs power equal to the difference between the load power and the power limit set by the GEG (upper set point), and at low load it loads it to the minimum set point (lower set point), while storing energy. In this way, the GEG load graph is smoothed, which allows to operate the generator unit in a more beneficial mode, minimizing fuel and motor resource consumption. Smoothing the load graph makes it possible to select the installed GEG power significantly less than the maximum load.

The test program included the following experiments:

1.Verification of ESS operability during the implementation of the first algorithm in the mode of limiting the rate of change in the GEG power during the increased and decreased load power at different work cycles of the load with different settings for the rate of change of power.

2. Verification of ESS operability during implementation of the second algorithm in the mode of limiting maximum and minimum GEG power for different load cycles with different setpoints.

\subsection{Results of the first algorithm - "dP/dt compensation mode"}

In testing, the rate of change in the summing power generated by the GEG 1 and 2 was limited to $22.5 \mathrm{~kW} / \mathrm{s}$ - $1 \%$ of the summing power $(2250 \mathrm{~kW})$ of the two GEGs. The exponential change of the power was realized in the ESS control algorithm.

In the experiments the modes of ESS operation were explored for the compensation of surges and sheddings of different loads power - 100, 200, 400, 600, 800, 1200 $\mathrm{kW}$.

The test scheme is shown in Figure 2.

The initial state of the scheme:

- switches Q4.1-Q4.3 are off;

- switches Q1, Q2, Q4.4-Q4.6 are on;

- the load is $800 \mathrm{~kW}$;

- ESS is in standby mode.

Different operating cycles of load changes were simulated by switching the active load resistances. The basic, unplugged load was $35-40 \mathrm{~kW}$ (power supply to the load fans, lighting and appliancies).

Instantaneous values of GEG1, GEG2, ESS currents and $10 \mathrm{kV}$ bus voltages were recorded by a digital 
oscilloscope with a sampling rate of $25 \mathrm{kHz}$. All other instantaneous values of the mode parameters were calculated on their basis.

A fragment of an oscillogram obtained during the implementation of the first operating cycle is shown in Figure 3. Without implementation of the ESS, it would be impossible to have such a load graph - the technological protection system of the GEG would shut it down at the first power surge. At the initial moment, the ESS fully "takes over" the load surge or drop and smoothly " passes" it to the GEG according to the exponential law.

Fig. 3. Oscillogram of load power, ESS power, GEG power and frequency at permissible power change rate (setpoint) $22.5 \mathrm{~kW} / \mathrm{s}$.
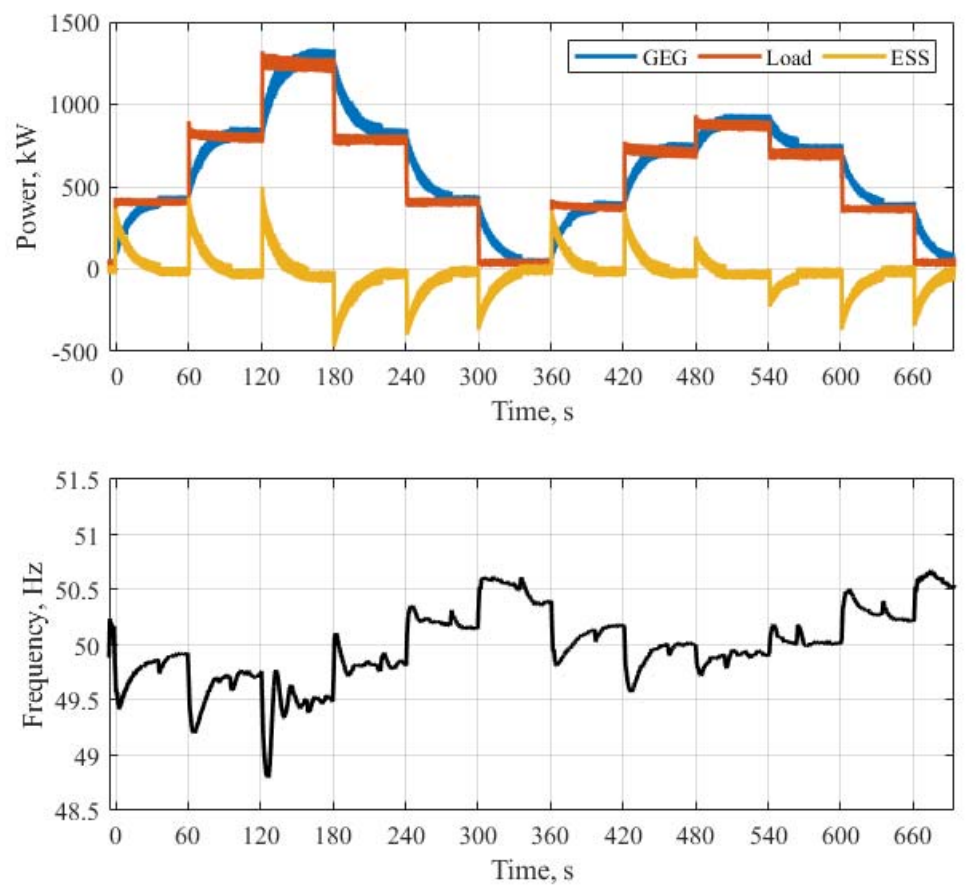

A fragment of an oscillogram obtained by implementing the second operating cycle is shown in Figure 4. The experiment has shown high efficiency of ESS for limiting the rate of power change in the GEG at surges/sheddings in the range much larger than in the previous case - 800 and $1200 \mathrm{~kW}$. Without ESS, such power surges may lead to the emergency triggering of the protection system and shutdown of the GEG.

Figure 5 shows the oscillograms obtained during the third operating cycle, performed at a higher load change frequency. The load varied on a large scale every 10 seconds and since the permissible power change rate of the GEG was assumed to be the same as in the experiments described above, so the GEG failed to achieve full load coverage. Due to this fact, with a high frequency of abrupt load changes, a much larger part of its variable component of the load is provided by ESS.

In all the experiments described above, the ESS switched to the mode of power output at each load surge, and at sheddings to the mode of excess consumption of power from the GEG, acting as a damper.

Figures 6 and 7 show oscillograms of frequency, ESS, GEG power and load at the critical value of load shedding from 1200 to $1000 \mathrm{~kW}$ with and without ESS. In these experiments, the same control algorithm as described above was implemented. Transient processes with the ESS run with significantly lower deviations of mode parameters, first of all, frequency, than without
ESS, which positively affects the operating conditions of the GEG and confirms the efficiency of the implemented control algorithm.

During the implementation of the first algorithm, in all the experiments carried out there were no shutdowns of the GEG by the technological protection system caused by surges and sheddings in the load power. The reaction time of the ESS to the load power surge/drop was not more than $10 \mathrm{~ms}$. The quality of transition processes has significantly improved. The improved operability of ESS has been confirmed and the efficiency of the control algorithm for smoothing load power surges has been shown.

\subsection{Implementation of the second algorithm - "power limitation mode"}

During this test, the ESS with pre-charged SS batteries worked on limiting the summing maximum and minimum power of the two GEGs (the lower set point is $900 \mathrm{~kW}$, the upper set point is $1100 \mathrm{~kW}$ ). When the load power went beyond the set-point values, the difference between the set-point and actual load was compensated by the ESS. The experimental scheme and initial test conditions were the same as in the previous case.

In the tests, abruptly variable graph of the load power variation from $800 \mathrm{~kW}$ to $1200 \mathrm{~kW}$ was set. The reaction time of the ESS to changes in the load power did not exceed the set limit of $20 \mathrm{~ms}$, and the power generated 
by the GEG 1 and 2 did not exceed the set limits of $900 \quad$ and $1100 \mathrm{~kW}$ (Figure 8).
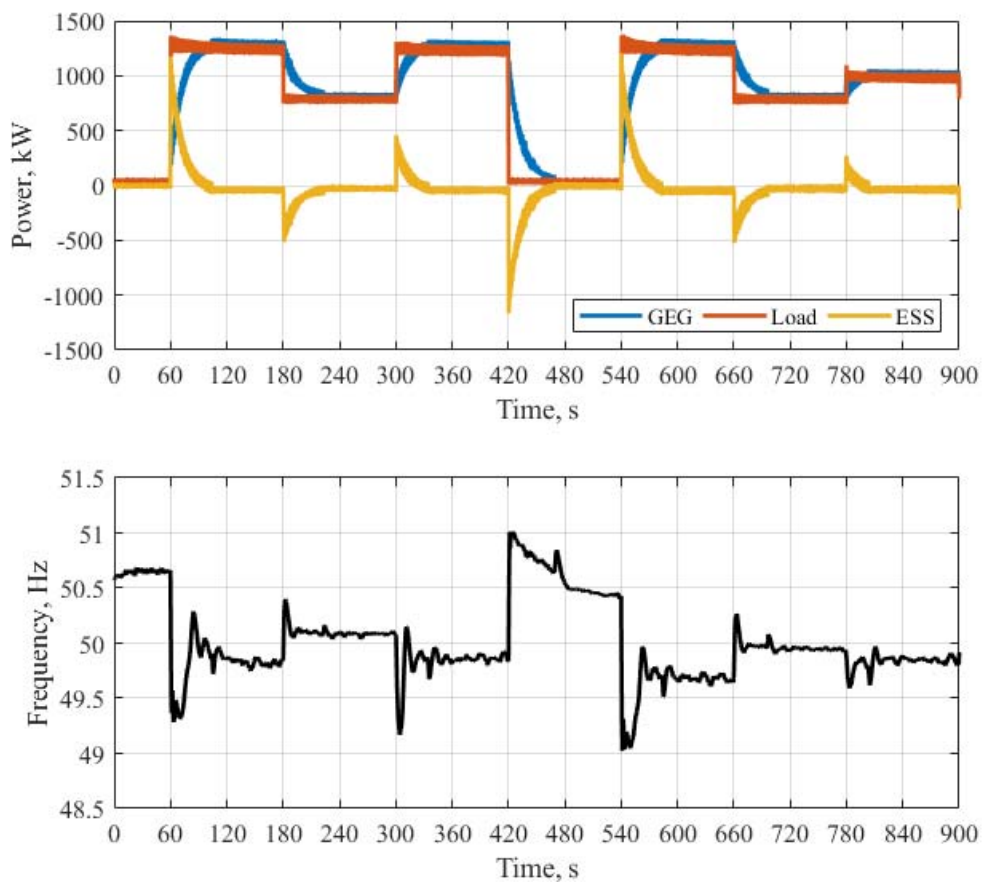

Fig. 4. Oscillograms of load power, ESS power, GEG power and instantaneous frequency value on GEG buses at permissible power change rate (setpoint) $22.5 \mathrm{~kW} / \mathrm{s}$.
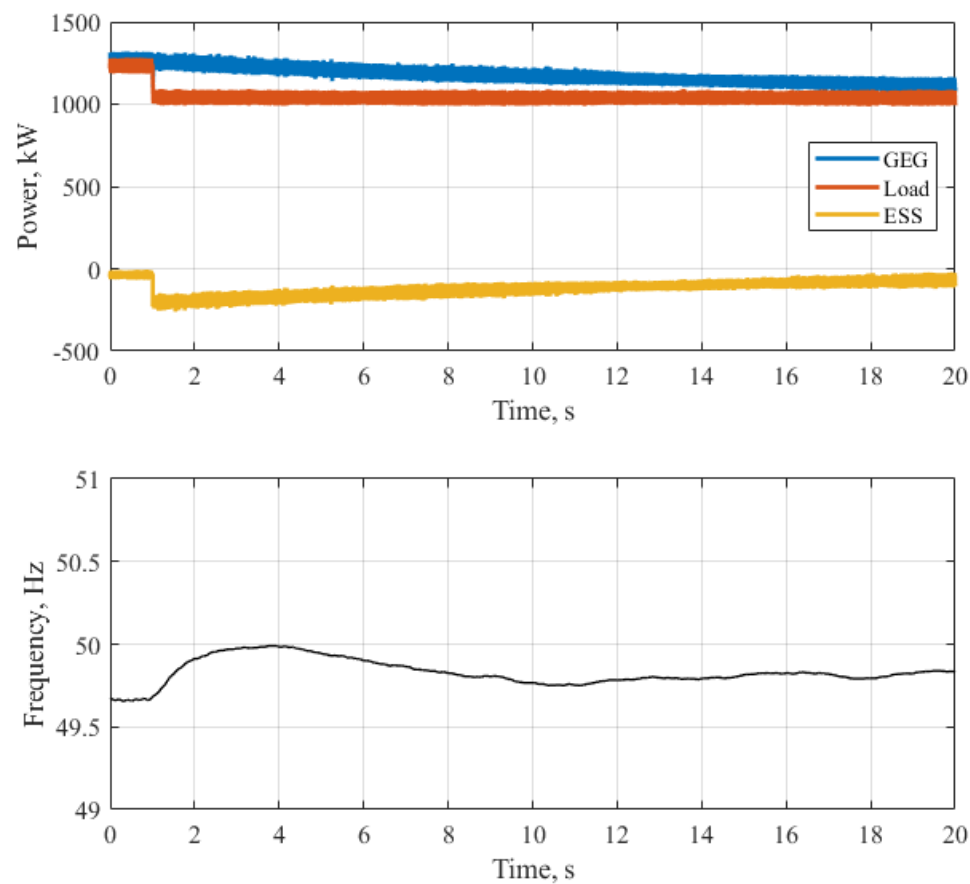

Fig. 5. Oscillograms of load power, ESS power, GEG power and instantaneous frequency value on GEG buses at permissible power change rate (setpoint) $22.5 \mathrm{~kW} / \mathrm{s}$.

Fig. 6. Oscillograms of load power, ESS power, GEG power and instantaneous frequency value on GEG buses without ESS when resetting load power from $1200 \mathrm{~kW}$ to $1000 \mathrm{~kW}$. 



Fig. 7. Oscillograms of load power, ESS power, GEG power and instantaneous frequency value on GEG buses with ESS when the load power is reset from $1200 \mathrm{~kW}$ to $1000 \mathrm{~kW}$.

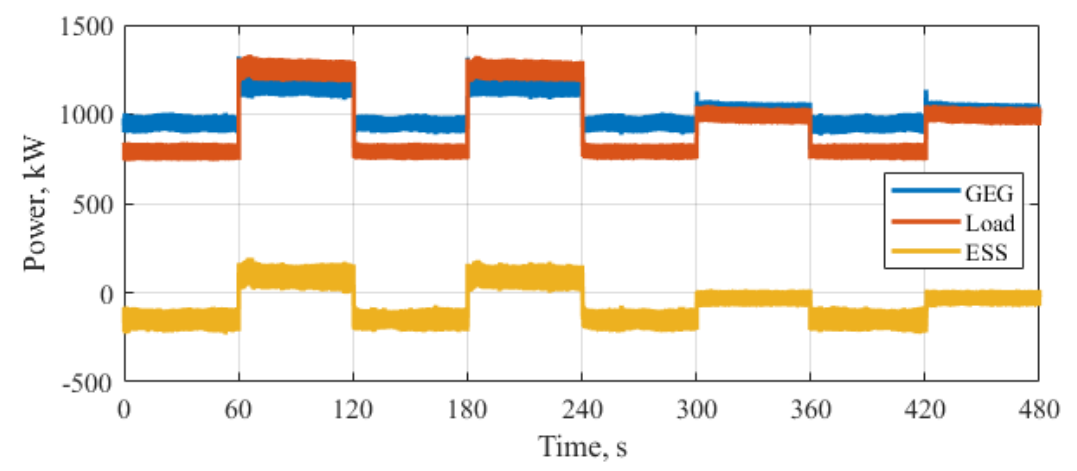

Fig. 8. Oscillograms of load power, ESS power, GEG power with minimum and maximum GEG power limitation.

Based on the same graphs, but with different power range limitations, a number of experiments were carried out, confirming the high efficiency of ESS to solve the problem. When the upper and lower setting values converge, it results in more smoothing of the GEG power graph and its approximation to the average value of the load power graph allows the GEG to work in a more economical mode with less specific fuel consumption. In addition, it is possible to replace the "standard" generator unit with a unit of smaller capacity that is close to the average capacity value of the load graph. Regulation of the variable part of the load graph is fully due to the ESS in this case. In this process, a complex effect is achieved: the minimal specific fuel consumption, the minimal cost of the unit, the minimal cost of its maintenance, increased motor resource of the drive engine, reduced losses in the generator from transients caused by abruptly variable load.

The response time of the ESS on change of load power during the experiments was not more than $10 \mathrm{~ms}$, and the summing output power GEG1 and GEG2 did not go beyond the predetermined limits - lower and upper power setpoint.

\section{Conclusion}

The tests conducted in the Russian Federation for the first time on the industrial sample of energy storage system ESS-10-1200-400 (power $1200 \mathrm{kVA}$ and energy capacity $400 \mathrm{kWh}$ ) in combination with GEGs on the abruptly variable load as part of the experimental unit confirmed the operability of all subsystems of ESS and 
high efficiency of the proposed algorithms. Implemented algorithms of ESS control have significantly improved the operating conditions of the GEG by a significant reduction in the intensity of transient processes, which resulted in improved technical and economic characteristics of the GEG. Application of ESS together with the GEG operating on an abruptly variable load allows limiting the rate of power change of generator to permissible values. This significantly reduces the requirements to the type of generator unit operating on an abruptly variable load, which is especially important for off-grid power systems using GEGs. In addition, when limiting the rate of power change of the generator, which working on an abruptly variable load greatly reduces the amplitude of torque moments on the shaft of the generator, provides a more beneficial mode of its operation, reduces fuel consumption, saving the motor resource of the GEG.

The use of ESS in the mode of limiting the maximum and minimum load on the GEG allows to operate the GEG without the risk of shutdown by technological protection system at the abruptly variable graph of load and in low load modes. Also, a significant economic effect can be achieved by selecting a generator unit not by the maximum load capacity, but by limiting its peaks. Due to this, capital expenditures on the main equipment, spare parts and operating costs are reduced and specific fuel consumption is reduced [5]. The greatest effect from replacement of a powerful GEG with a unit of lower power in terms of fuel consumption is achieved at low values of the coefficient of the rated power of the unit which is replaced.

\section{References}

1. Gibridnyj nakopitel' energii dlya ENES na baze akkumulyatorov i superkondensatorov [Hybrid energy storage for the Unified National Electric Power Station based on the accumulators and supercapacitors] / R.N. Berdnikov, V.E. Fortov, YU.G. SHakaryan, K.K. Den'shchikov // Energiya edinoj seti [Energy of the unified network]. (2013). - №1 . - pp.40-51. [in Russian]

2. Zobaa, A.F. Energy storage technologies and applications. Rijeka, Croatia: Intech, (2013)., - 328 pp.

3. Effekty primeneniya nakopitelej energii $\mathrm{V}$ izolirovannyh energosistemah Rossii [Application Effects of the energy storage devices in the isolated energy systems of Russia] / V.YU. Kononenko, O.V. Veshchunov, V.P. Bilashenko, D.O.Smolencev // Arktika: ekologiya i ekonomika [Arctic: Ecology and Economics]. - (2014). - №2 (14). - pp.61-66. [in Russian]

4. Koncepciya razvitiya rynka sistem hraneniya elektroenergii [Concept of Development of the Electric Power Storage Systems Market]/ Ministerstvo energetiki Rossijskoj Federacii [Ministry of Energy of the Russian Federation]. URL: https://minenergo.gov.ru/node/9029. [in Russian]
5. Eksperimental'nye issledovaniya i ispytaniya sovmestnoj raboty sistemy nakopleniya energii i DGU $v$ sostave avtonomnoj energosistemy [Experimental studies and tests of the joint operation of the energy storage system and the DGU as a part of an autonomous power system] / Zyryanov V.M., Kuchak S.V., Bachurin P.A., Haritonov S.A., Metal'nikov D.G., Garmash T.G., Voroshilov A.N., Frolov D.A. // Promyshlennaya energetika [Industrial Energy]. - (2018). - № 10. - pp.2-10. [in Russian]

6. Effektivnoe ispol'zovanie nakopitelej elektricheskoj energii dlya predotvrashcheniya otklyuchenij ob"ektov raspredelennoj generacii pri kratkovremennyh otkloneniyah chastoty [Effective use of the electric energy accumulators for prevention of the distributed generation objects switching-off at the short-term frequency deviation] / Ilyushin P.V., Kulikov A.L., Berezovskij P.K. // Relejnaya zashchita i avtomatizaciya [Relay protection and automation]. - (2019). - № 4. - pp. 32-39. [in Russian]

7. Gazovyj dvigatel' TCG 2020 [Elektronnyj resurs] [TCG 2020 gas engine [Electronic resource]]: https://www.mwm.com.ru/gazovye-dvigateliblochnye-tehc/gazovye-dvigateli-generatorynyeustanovki/tcg-2020/ [in Russian]

8. Tekhnicheskaya karta GBS-LFP100AH [Elektronnyj resurs] [Technical card GBSLFP100AH [Electronic resource]]: https://prometheusenergy.ru/product/litij-ionnyjakkumulyator-gbs-lfp100ah-a/ [in Russian]

9. Akagi. H. Instantaneous Power Theory and Applications to Power Condi-tioning / H. Akagi, E.H. Watanabe, M. Aredes // IEE Press, John Wiley and Sons Inc. (2007). - P. 389.

10. Dybko M. A. Active power filter with battery energy storage based on NPC inverters / M. A. Dybko, S. V. Brovanov // 16 International conference of young specialists on micro/nanotechnologies and electron devices (EDM): [proc.], Altai, Erlagol, 29 June - 3 July 2015. - IEEE, (2015). - P. 415-421. 